\title{
Analysis of the Thematic Overlap Between Library and Information Science and Other Subdisciplines of the Social Communication and Media Sciences in Poland
}

\author{
Zbigniew Osiński \\ ORCID 0000-0003-4484-7265 \\ Department of Digital Humanities, Faculty of Humanities, \\ Maria Curie-Skłodowska University in Lublin
}

\begin{abstract}
Purpose/Thesis: The recent decision to join three previously separate disciplines - library and information science, media studies, and cognition and social communication science, into a single discipline of social communication and media sciences prompted the author to investigate if joining of these disciplines according to the compulsory categorization published by the OECD, is supported by an overlap in their fields of research, or by a similarity in their methods of conducting it.

Approach/Methods: An analysis of the review articles devoted to the research fields of all three disciplines, and of the information regarding the research interests of the journals affiliated with them, as published on the journals' websites, allowed the author to establish their thematic scope. The results of this analysis were compared with bibliographic data and sets of keywords found in the affiliated journals. The comparison relied on an analysis of citations, and of coexistence of specialized terms. Results and conclusions: The analysis of the review articles suggested that the basic research fields of library and information science and of the media studies and cognition and social communication science are aligned and complement each other. This conclusion was further supported by the analysis of the guidelines for the potential contributors provided on the websites of the investigated journals. However, the analysis of the bibliographic data and of the keyword sets gave an entirely different idea of the relation between the studied disciplines, indicating that there is no significant thematic overlap between them. Nevertheless, this might be due to the quality of this particular data sample, and to the methods' susceptibility to data disruption.

Originality/Value: The article proves that there is an overlap between library and information science, and the social communication and media sciences. Furthermore, it shows the limits of the citation method and of the specialized terms coexistence method, resulting from the practices of the authors and the editorial teams of some of the journals discussed. The article shows that all quantitative studies of the state of scholarship in a given discipline in Poland must be conducted with great care, and their results should not be the only basis for conclusions.
\end{abstract}

\section{Keywords}

Bibliographic coupling method. Cognition and social communication sciences. Library and Information Science. Media studies. Social communication and media sciences. Specialized terms coexistence method.

Received: 23 September 2019. Reviewed: 21 October 2019. Revised: 22 October 2019. Accepted: 18 November 2019. 


\section{Introduction}

The regulation issued by the Ministry of Science and Higher Education in Poland on September 20th, 2018 regarding the new classification of the fields of science and scientific disciplines as well as artistic disciplines (Rozporzadzenie Ministra Nauki i Szkolnictwa Wyższego z dnia 20 września 2018 r. w sprawie dziedzin nauki i dyscyplin naukowych oraz dyscyplin artystycznych) joined three previously separate disciplines, library and information science (humanities), media studies, and cognitive and social communication science (social sciences) into a single new discipline, social communication and media sciences (social science). The decision was justified as an improvement to the previous artificial narrowing of the research fields, which would adjust the Polish classification of the fields of science and scientific disciplines to the international standards, particularly those established by the OECD, and allow it to meet the demands of the new methodology of the evaluation of research conducted at particular institutions (KDN, 2018). It bears reminding that the OECD classification differs from the classification applied by the most important international bibliographic databases, Web of Science and Scopus, on which the Ministry's list of scoring journals and rules of evaluation of scientific disciplines are based. Both of these bibliographic databases clearly distinguish between Communication Science, and Library and Information Sciences (Information Science \& Library Science in WoS). It therefore becomes pertinent to ask if the joining of library and information science with media studies and cognitive and social communication sciences might be justified by an overlap in their research fields; if the academics from these disciplines take similar approaches to their research; and if these disciplines can be sensibly identified as a new joint discipline.

\section{Literature review}

We find in Polish scholarship studies devoted to the thematic scope of all three disciplines under discussion. Because of the focus and goals of this study, which is concerned with the Polish academic environment, the literature review prioritized the most recent publications of Polish academics.

Tomasz Globan-Klas (2008) described the object of study and the research field of a discipline which he called media and social communication studies. Among its primary research interests he included mass media and mass communication, i.e. communication mediated by the use of public and collective media. In his estimation, the rise of the Internet brought the object of study and the research field of media and social communication studies increasingly closer to these previously specific to the study of individual and group communication (the psychology of interpersonal communication), which impacts the study of communication codes (linguistics; cognitive and social communication science; semiotics; nonverbal communication), for the study of immediate group communication (rhetoric, theater studies), and for the specialized communication sciences (computer science, telecommunication).

Arguing for a formal recognition of the discipline of communication and social media studies, Janusz W. Adamowski (2009), listed history of media and journalism, sociology 
of journalism, legal basis of media activity, linguistics of media, the effect of media on the socio-economy and politics, and communication in politics, business, and culture among the discipline's research interests.

For Małgorzata Lisowska-Magdziarz (2013), the media and social communication science distinguishes itself by posing research questions which would not be prioritized by other disciplines, although they might feature as complementary questions, subordinated to their respective research interests. In the media and social communication science, these questions are not a means to another end, but the focus of research. The research field of this discipline encompasses the author of mediated content and its the recipient; the mediation and content of mass media; the relations between authors and recipients; the comprehension of mediated content; the effect of media on individuals and collectives; the influence of media on human behavior; the source/sender institutions and organizations; the technology and means of communication; the economy of media; the position and role of mass media in the culture and society. With the development of the digital media and of the Internet, the field extended to include the issues of the virtual, the visual, transmediality, transculturality, multimediality, the convergence of media, interactivity and mediatization. These issues are studied within an empirical framework, presuming the existence of an empirically knowable and intersubjectively describable reality, which it is possible to analyze following the precisely described methods of constructivism, which focuses on the processes and ways in which the authors and the recipients of mediated content construe their world, creating their meanings.

Marek Jabłonowski and Tomasz Gackowski (2012) distinguished the following fields of research in the media studies: theory of mass media; the study of the influence of media; the study of the content of media; the language of media; the history of media and journalism; the economy of media; media public relations and marketing; media management and logistics; the aesthetics of media; political communication; media audiences.

According to Marek Jabłonowski and Wojciech Jakubowski (2014), media studies are simultaneously within the research field of the arts disciplines (the linguistics, literature studies, history, culture and anthropology, and theology of media), and of the social sciences (the political, psycho-social, and economic conditions of the operation of the mass media, and their effect on the audience). Furthermore, they stated that media studies are concerned not only with the mass media (press, radio, television, Internet), but also the individual who communicates and mediates, and who is susceptible to the media's influence. The research on these subjects has three distinct aspects: cognitive, communicological, and medialogical. The authors posit that in Poland, cognitive and social communication science has an existence separate from media studies. Three strands of research are to be distinguished in the mass media: history of media, theory of media, and several sub-fields: anthropology of media, pedagogy of media, philosophy of media, media law. Furthermore, the authors presented a detailed list of research areas of media studies, based on Nauka o Mediach (Media Studies), an official publication prepared by J.W. Adamowski, M. Jabłonoswski and K.A. Wojtaszczyk for the Central Commission for Academic Degrees and Titles. These included: the circulation of information facilitated by media; the relation between the consciousness of the recipients of the mediated content, the mediated content, and the purposes of the authors of the mediated content; the use of media in the changing society and media environment; legal, economical, and political conditions of the functioning of 
media; the specifics of the structures within media institutions; developing tools allowing an estimation and prediction of the influence of media on the consciousness of the recipients and on the public opinion; constructing models representing the functioning of media systems; developing tools for the analysis of the mediated content as a historical source; describing media history; the study of the offer of particular sources of mediated content; analysis of the media convergence.

The communication science was defined by Bogusława Dobek-Ostrowska (2006), among others. According to her, its research field encompasses all elements, stages, and aspects of the social communication process, immediate (interpersonal communication) as well as mediated (with the use of media). Thus defined, the communication science is characterized by its interdisciplinary methodological approach, as it borrows from the methodology of sociology, psychology, psychiatry, history and mathematics.

However, Emanuel Kulczycki (2008) claims that all issues identified as objects of study of the communication science are in fact objects of study for other academic disciplines, such as sociology, linguistics, psychology, ethics, and so on, while the communication science itself is only one of the research fields shared by these disciplines. He stated that there is a vast difference between an interdisciplinary research field and an independent academic discipline, with distinct aims and methodology. He argued that (2011):

\footnotetext{
Communication science is not to be identified with communicology, nor with the discipline of communication (to be understood as a consideration of the communication process, which is characterized by its status as an autonomous discipline). What is called 'communication science' (and identified with communicology) in Poland, is a type of an interdisciplinary research method or rather, a type of a research field shared by multiple disciplines, studied within the framework of specific subdisciplines (e.g. psychology or communication sociology).
}

It is worth mentioning that all scholars discussed thus far join media studies with communication science, without consideration of cognitive science, which is more commonly considered a part of philosophy and psychology. If epistemology, cognition, and psychology are not involved in cognitive and social communication science, only social communication science remains. Furthermore, social communication is identified with an immediate interpersonal communication (face-to-face), which is an object of study in linguistics and psychology. Thus, media studies should be joined only with the study of mediated social communication (Goban-Klas, 2009). Meanwhile, J.W. Adamowski suggested that cognitive and communication sciences have more in common with culture studies than they do with media studies (2009).

Regarding the information science, Barbara-Sosińska-Kalata (2013) defined following issues as the research interests of the discipline: the analysis of the state and the development of information and knowledge resources within different branches and specializations; information architecture and usability of internet websites; digital archives, libraries, and repositories; user studies - information needs, information literacy, and information behaviors; information barriers; history and contemporary nature of the book and of the library; quantitative research of information use - bibliometrics, scientometrics, webometrics; library science; information economy; information ethics; scholarly communication; information in digital and social media; knowledge organization - folksonomy, indexing, metadata, ontology, theory of classification and knowledge organization; theory of information; methodology and terminology of information science; data mining and text 
mining; big data; systems for the automatic content identification and extraction; expert systems and artificial intelligence; technology of information processing and publishing; information services; digitization and visualization of information; information retrieval and evaluation; information management; information sources. This set of research interests was met with acceptance of the Polish academic community, which became evident when it gave the basis for a textbook Nauka o informacji (Information Science) published in 2016 with Wiesław Babik as the head editor.

Writing in Nauka o informacji, Mirosław Górny (2016) stated that every research field of information science might be put into one of four broad categories:

- the discovery of qualities and characteristics of information objects and information processes;

- the study of the functions of information objects and information processes;

- the clarification of the mechanisms of information processes, and all other processes occurring in the information infrastructure;

- the design and modernization of information systems.

Hanna Batorowska (2015) highlighted the new challenges to the information science posed by the development of information and communication technology, which included the study of information culture, development of information literacy, information education, and information ecology.

The introduction of the Ministry's new classification of academic disciplines opened a discussion of a potential relation between the previously separate disciplines, now joined into social communication and media sciences. Marek Jabłonowski and Tomasz Mielczarek (2018) opined that the joining of media studies, cognitive and social communication science, and library and information science did not open new research fields, nor did it suggest new research questions. For example, the book, which is the main object of study for library science, is of interest to media studies as well, because it might be considered as a medium for communication of content, as it is to the cognitive and social communication science, which views it as a source of knowledge and as a means to communicate content. Information, the central focus of the information science, has also been studied by the scholars affiliated with the other two disciplines, as an effect of the operation of media, and as a basis for knowledge and communication. Furthermore, the approaches to, and methods of conducting research within all three disciplines show similarities. Jabłonowski and Mielczarek concluded that the joining of these disciplines will not disrupt their paradigms and methodologies, but instead it will allow for a creation of interdisciplinary research teams who will view given objects of study from multiple perspectives. In the future, the objects of study, research methods and approaches, and paradigms, may converge.

\section{Aim, methods}

As discussed in the introduction, the aim of this study is to establish whether the decision to join the disciplines of information and library science, media studies, and cognitive science, into one discipline in the new Polish system of classification, based on the OECD system, might be justified by their sharing of study objects, and by overlaps between the 
areas of, and approaches to, previously conducted research. To answer these questions we may follow the example of B. Sosińska-Kalata (2013) and conduct a thematic analysis of the articles published in the journals considered to be the most important sources of new scholarship within the studied disciplines. We may also use a shortcut and analyze the content of review articles concerned with the research interests of these disciplines, and the thematic scope of the abovementioned select journals, available on their websites. The author chose the second approach, and studied the previously discussed review articles. Regarding the journals, they had to meet two criteria to be chosen for further study: they had to be included on the Polish Ministry's list of scoring journals in 2018 and they had to made their content fully available online, at least the content published between 2010-2018. Thus, the following journals were selected:

(1) concerned with library and information science: Annales Universitatis Paedagogicae Caracoviensis. Studia ad Bibliothecarum Scientiam Pertinentia (The Pedagogic Yearbook[s] of the Cracow University. The Current Studies in the Library Science); Praktyka i Teoria Informacji Naukowej i Technicznej (Practice and Theory of Scientific and Technical Information), Przegląd Biblioteczny (Library Review), Studia o Książce i Informacji (Book and Information Studies), Toruńskie Studia Bibliologiczne (Toruń Bibliological Studies), Zagadnienia Informacji Naukowej - Studia Informacyjne (Issues in Information Science - Information Studies).

(2) concerned with media studies and cognitive and social communication sciences: Central European Journal of Communication, Media - Kultura - Komunikacja Społeczna (Media - Culture - Social Communication), Naukowy Przegląd Dziennikarski (Journalism Research Review Quarterly), Rocznik Bibliologiczno-Prasoznawczy (Yearbook of Bibliology and Press Studies), Rocznik Prasoznawczy (Yearbook of Press Studies), Studia Medioznawcze (Media Studies), Zeszyty Prasoznawcze (Media Research Issues).

The author chose not to analyze the articles published by Polish scholars in foreign journals, as they are so rare they would not contribute to the results of the study.

The collected data was compared with the results of a quantitative research to see if the results of the qualitative study (the analysis of the review articles and the websites) would be supported by the quantitative methods, which are increasingly popular in humanities and social sciences. The comparison was further motivated by E. Kulczycki's (2008) observation that overlaps between research fields of various disciplines did not indicate that they are related. For example, 'the child,' or 'the family', are studied within both sociology and medicine, which are disciplines separated by a great distance. Many disciplines shares research objects, but in most cases, it does not inspire collaborative interdisciplinary research, because the differences in methodology and research aims are too vast. Therefore, the author relied on the quantitative data, the analysis of citations (although initially, the bibliographic coupling method was considered), and the specialized terms coexistence method, to verify the initial conclusions based on the qualitative data.

The method of generating bibliographic couplings is based on the premise that the works which occupy identical bibliographic positions will have similar content. The more bibliographic positions they share, the more similar their content should be. The method involves searching for publications which share at least one such bibliographic position and creating thematic clusters, which would contain the works presumed to 
contain similar content (Kessler, 1963). However, because the instances in which the groups of articles containing at least one article from the discipline of library and information science and one from media studies and cognitive and social communication sciences, sharing at least one bibliographic position, were exceedingly rare, the author did not use this method.

Instead, the author prioritized searching for the articles whose bibliographies included at least one work published in one of the journals under the consideration (see the list above), i.e. the method of citation analysis. It was assumed that if citing the works from one journal in the articles published in another journal would be regular, rather than incidental, it would suggest a thematic overlap between these journals, and, implicitly, between the academic disciplines with which they are affiliated.

The specialized terms coexistence method involves browsing for terms featuring in the titles, keywords, abstracts and full texts of the compared publications, or groups thereof (a journal would be such a group). The use of the same specialized terms without variations in their referents, indicates a thematic overlap. The higher the number of shared specialized terms, the stronger the overlap. The author analyzed the keywords of all the articles whose bibliography contained at least one work published in one of the studied journals. He thus collected two sets of data, one for the journals associated with the library and information science, and the other with the media studies and cognition and social communication science. The frequency with which the specific specialized terms appeared, with a division between single words and longer phrases, was calculated using the internet application Calculla (https://calculla.pl/licznik_slow).

\section{Results}

The analysis of the articles discussed in the literature review section allowed the author to put forward a thesis that the basic research fields of the library and information science, and of media studies and the cognitive and social communication sciences, are aligned and complementary (Tab. 1).

The discussed disciplines are concerned with sources and resources of information, which include media, and the users thereof, as well as with their influence on the individual, the society, and the communication processes. Although historically, they have focused on different objects of study - books, recorded information, and libraries in the case of the library and information science, and press, radio, and television in the case of the other two disciplines, all three analyze the Internet. The information user and the participant in the communication processes, i.e., the individual and the society, constitute another object of study all three disciplines share.

This observation is confirmed by the analysis of the guidelines for the potential authors, as published on the websites of the studied journals (Tab. 2).

The data collected in Table 2 shows that, in a very general sense, the journals representative of the disciplines under discussion, are concerned with similar research fields and objects of study. They differ where they prioritize different specific aspects of these fields and objects. Journals and online social media might be studied either as sources of information, or as species of mass media and mass communication tools. Linguistic 
aspects might be discussed either in relation to information architecture, or to the construction of messages in traditional or digital media. All three disciplines consider how the individual and the society might be affected - either by information processes, or by media and mass communication processes. Among the interests of the researchers is the issue of digitalization, either in the libraries, or in the digital media. The architecture of information is studied as a part of a wider discussion regarding data repositories and websites, as well as an aspect of a media. Information and digital literacies are aspects of both the information environment and the media environment. The academics research mass communication in the domains of politics and economy, as well as in the domain of science. The development of culture is analyzed with the use of case studies from media, but also from libraries. Significant differences between the three disciplines emerge only in the details of their research questions.

The citation analysis was conducted on a data sample of 1432 articles published in the journals discussed above, between years 2010-2018, available online (Tab. 3).

Tab. 1. The basic research fields of the analyzed disciplines

\begin{tabular}{|c|c|}
\hline Information \& library science & $\begin{array}{l}\text { Media studies and cognition } \\
\text { \& social communication science }\end{array}$ \\
\hline $\begin{array}{l}\text { The history of the library and of the book } \\
\text { The functioning of libraries, publishing } \\
\text { houses, repositories, and other information } \\
\text { resources } \\
\text { Information theory } \\
\text { Information ethics } \\
\text { Information technology; media } \\
\text { Legal aspects of information } \\
\text { Linguistic aspects of information } \\
\text { Information literacy, information competen- } \\
\text { ces } \\
\text { Information users } \\
\text { Information processes and their quality } \\
\text { The organization and architecture of infor- } \\
\text { mation } \\
\text { The relations between authors and recipients } \\
\text { Digitalization, multimedia, and the Internet } \\
\text { Scientific communication } \\
\text { Information society } \\
\text { Quantitative research - bibliometrics, webo- } \\
\text { metrics } \\
\text { Information economy } \\
\text { Information culture }\end{array}$ & $\begin{array}{l}\text { The history of media and journalism } \\
\text { The functioning of media } \\
\text { Theory of media and communication } \\
\text { Media ethics } \\
\text { Media technology } \\
\text { Media law } \\
\text { Linguistic aspects of media's functioning } \\
\text { (Linguistics of media) } \\
\text { Media pedagogy } \\
\text { Media audiences } \\
\text { Communication and cognitive processes; } \\
\text { their quality } \\
\text { The organization and architecture of media } \\
\text { content } \\
\text { The relations between media creators and } \\
\text { audiences } \\
\text { Digitalization, multimedia, and the Internet } \\
\text { Political and marketing communication } \\
\text { The social influence of media } \\
\text { Information society } \\
\text { Quantitative research - audience measure- } \\
\text { ment, reaching target audiences, changing } \\
\text { preferences } \\
\text { Media economy } \\
\text { Culture in media; media in culture }\end{array}$ \\
\hline
\end{tabular}


Tab. 2. The thematic scope of the articles published in the studied journals

\begin{tabular}{|c|c|c|}
\hline Discipline & Journal & Thematic scope \\
\hline \multirow{6}{*}{$\begin{array}{l}\text { Library } \\
\text { \& information } \\
\text { science }\end{array}$} & $\begin{array}{l}\text { Annales Universitatis } \\
\text { Paedagogicae Cracoviensis. } \\
\text { Studia ad Bibliothecarum } \\
\text { Scientiam Pertinentia }\end{array}$ & $\begin{array}{l}\text { scientific information; } \\
\text { book and library history; } \\
\text { journals, literary culture }\end{array}$ \\
\hline & $\begin{array}{l}\text { Praktyka i Teoria } \\
\text { Informacji Naukowej } \\
\text { i Technicznej }\end{array}$ & $\begin{array}{l}\text { the field of scientific information (information } \\
\text { science) and related ideas; } \\
\text { current theoretical and practical issues which } \\
\text { are of interest to the creators and users of } \\
\text { information (considered in interdisciplinary } \\
\text { perspective) }\end{array}$ \\
\hline & Przegląd Biblioteczny & $\begin{array}{l}\text { contemporary research trends in library science, } \\
\text { book studies, bibliography and scientific infor- } \\
\text { mation }\end{array}$ \\
\hline & $\begin{array}{l}\text { Studia o Książce } \\
\text { i Informacji }\end{array}$ & $\begin{array}{l}\text { theory and practice of bibliology; } \\
\text { the aesthetics of the book; } \\
\text { modern media forms, contemporary publishing } \\
\text { market in Poland and in the World }\end{array}$ \\
\hline & $\begin{array}{l}\text { Toruńskie Studia } \\
\text { Bibliologiczne }\end{array}$ & $\begin{array}{l}\text { issues in the field of social communication and } \\
\text { media, including bibliology and information } \\
\text { science and related sub-disciplines, such as } \\
\text { media studies, archival studies and document } \\
\text { management, journalism, media art }\end{array}$ \\
\hline & $\begin{array}{l}\text { Zagadnienia Informacji } \\
\text { Naukowej }\end{array}$ & $\begin{array}{l}\text { information science in relation to library } \\
\text { science, archival science, museology and other } \\
\text { disciplines researching preservation and access } \\
\text { to scientific and cultural heritage; } \\
\text { information and knowledge management; } \\
\text { traditional and digital scholarly communication; } \\
\text { information and knowledge organization; meta- } \\
\text { data theory and practice; } \\
\text { Web 2.0; } \\
\text { Semantic Web; } \\
\text { information architecture; } \\
\text { information websites usability; } \\
\text { human-computer interaction; } \\
\text { natural language processing; } \\
\text { information retrieval; } \\
\text { information use and information users behavior; } \\
\text { social response to modern information techno- } \\
\text { logies; } \\
\text { digital humanities; information and digital } \\
\text { literacy; } \\
\text { information policy; } \\
\text { information ethics }\end{array}$ \\
\hline
\end{tabular}




\begin{tabular}{|c|c|c|}
\hline \multirow{7}{*}{$\begin{array}{l}\text { Media studies, } \\
\text { Cognition } \\
\text { and social } \\
\text { communica- } \\
\text { tion sciences }\end{array}$} & $\begin{array}{l}\text { Central European Journal } \\
\text { of Communication }\end{array}$ & $\begin{array}{l}\text { an international forum for empirical, critical } \\
\text { and interpretative, quantitative and qualitative } \\
\text { research examining the role of communication } \\
\text { in Central Europe and today's world; } \\
\text { media and communication studies }\end{array}$ \\
\hline & $\begin{array}{l}\text { Media - Kultura - } \\
\text { Komunikacja Społeczna }\end{array}$ & $\begin{array}{l}\text { press, radio, television, new media; } \\
\text { social communication in its theoretical and } \\
\text { practical aspects; } \\
\text { media politics, media law, media economics; } \\
\text { practical and ethical aspects of a journalist's } \\
\text { work; } \\
\text { the media as an integral element of the culture } \\
\text { system and culture in the media }\end{array}$ \\
\hline & $\begin{array}{l}\text { Naukowy Przegląd } \\
\text { Dziennikarski }\end{array}$ & $\begin{array}{l}\text { journalism (press, television, radio, Internet), its } \\
\text { history, theory and the newest trends }\end{array}$ \\
\hline & $\begin{array}{l}\text { Rocznik } \\
\text { Bibliologiczno-Prasoznaw- } \\
\text { czy }\end{array}$ & no information provided \\
\hline & Rocznik Prasoznawczy & $\begin{array}{l}\text { discussions of the newest theories, concepts and } \\
\text { problems relating to the media studies; } \\
\text { articles concerned with the widely understood } \\
\text { questions of media studies, and particularly with } \\
\text { the history of the press, theory of mass com- } \\
\text { munication, media systems and the culture of } \\
\text { language }\end{array}$ \\
\hline & Studia Medioznawcze & $\begin{array}{l}\text { the identity of the media studies; } \\
\text { new media; } \\
\text { ethics and public relations; } \\
\text { law in media; } \\
\text { history of media; } \\
\text { media in Poland - press, radio, television; } \\
\text { media environments abroad } \\
\end{array}$ \\
\hline & Zeszyty Prasoznawcze & $\begin{array}{l}\text { social, psychological, political, linguistic, legal, } \\
\text { economic, technological, organizational and } \\
\text { professional aspects of mass communication, } \\
\text { and in particular of the printed press, radio, } \\
\text { television and other media, journalism, adverti- } \\
\text { sing, propaganda and public opinion, in the past } \\
\text { and present, in Poland and abroad }\end{array}$ \\
\hline
\end{tabular}


Tab. 3. Quantitative results of the citation analysis of the articles published in the journals studied, as cited in other articles published in these journals

\begin{tabular}{|c|c|c|c|c|c|c|c|}
\hline No. & $\begin{array}{c}\text { The jour- } \\
\text { nal name } \\
\text { abbrevia- } \\
\text { ted) }\end{array}$ & $\begin{array}{c}\text { Number } \\
\text { of the } \\
\text { articles } \\
\text { studied }\end{array}$ & $\begin{array}{c}\text { Number of } \\
\text { the articles } \\
\text { citing } \\
\text { others }\end{array}$ & $\begin{array}{c}\text { Number } \\
\text { of cita- } \\
\text { tions }\end{array}$ & $\begin{array}{c}\text { Included: } \\
\text { self-cita- } \\
\text { tions }\end{array}$ & $\begin{array}{c}\text { Articles } \\
\text { with a cita- } \\
\text { tion number } \\
\text { of 1-2 }\end{array}$ & $\begin{array}{c}\text { Artic- } \\
\text { les with } \\
\text { a citation } \\
\text { number >3 }\end{array}$ \\
\hline 1 & ZIN & 123 & 48 & 91 & 26 & 36 & 12 \\
\hline 2 & PTINT & 152 & 44 & 75 & 18 & 38 & 6 \\
\hline 3 & PB & 139 & 51 & 99 & 19 & 41 & 10 \\
\hline 4 & TSB & 150 & 24 & 41 & 14 & 19 & 5 \\
\hline 5 & SKI & 25 & 4 & 4 & 0 & 4 & 0 \\
\hline 6 & AUPC & 70 & 20 & 30 & 6 & 17 & 3 \\
\hline 7 & MKKS & 128 & 19 & 42 & 4 & 11 & 8 \\
\hline 8 & ZP & 227 & 55 & 115 & 18 & 41 & 14 \\
\hline 9 & SM & 55 & 19 & 39 & 4 & 13 & 6 \\
\hline 10 & RBP & 58 & 21 & 46 & 8 & 16 & 5 \\
\hline 11 & RP & 43 & 5 & 7 & 1 & 5 & 0 \\
\hline 12 & NPD & 139 & 23 & 44 & 12 & 19 & 4 \\
\hline 13 & CEJC & 123 & 5 & 12 & 1 & 4 & 1 \\
\hline & Total & 1432 & 338 & 645 & 131 & 262 & 76 \\
\hline
\end{tabular}

Full names of the journals featured in the table: ZIN - Zagadnienia Informacji Naukowej, PTINT - Praktyka i Teoria Informacji Naukowej i Technicznej, PB - Przegląd Biblioteczny, TSB - Toruńskie Studia Bibliologiczne, SKI - Studia o Książce i Informacji, AUPC - Annales Universitatis Paedagogicae Cracoviensis. Studia ad Bibliothecarum Scientiam Pertinentia, MKKS - Media - Kultura - Komunikacja Społeczna, ZP - Zeszyty Prasoznawcze, SM - Studia Medioznawcze, RBP - Rocznik Bibliologiczno-Prasoznawczy, RP - Rocznik Prasoznawczy, NPD Naukowy Przegląd Dziennikarski, CEJC - Central European Journal of Communication.

The citation analysis firstly made manifest the limitations of this method, whose cause are the authors themselves and the editing teams of some of the journals studied. It is clear that the authors are reluctant to cite articles published in Polish journals (as well as articles by Polish authors published in foreign journals). Out of the 1432 articles studied, only 338 cites texts published in the Polish journals featured in the present research. These articles usually contain only one or two references to other papers published in the studied journals. The simplest explanation of this phenomenon, i.e., that the majority of the authors publishing in Polish journals concerned with the library and information science, media studies, and cognition and social communication sciences, is concerned with questions so original that no other publications on the subject might be found, is highly unlikely. A study of these articles' bibliographies clarifies the situation: it seems that the authors tend to refer to monographs and chapters of collaborative works (these citations account for $70-90 \%$ of the bibliographies). Unfortunately, these types of publications are much more rarely available online, and, because of the faults in the functioning of the legal deposit system, they are available only in a few libraries. Thus, it is much more difficult to access 
them, which makes a citation analysis of bibliographies of texts contained in such publications extremely time consuming and inefficient. This constitutes a serious limitation to the method of citation analysis. Further problems are generated by absence of the list of references in the end of articles in several journals, or particular issues of these journals, and by the confusion of primary and secondary sources in bibliographies that are attached to the articles. Without a careful reading of the article in its entirety, it is difficult to tell whether a particular position in the list of references (even if it is an article published in a peer-reviewed journal) was used as a secondary or a primary source. In a number of articles secondary sources constituted only a small part of their references. It is possible to describe certain articles studied as completely lacking in reference to secondary sources, as their lists of references contained only a list of the primary sources used.

Reading the texts concerned with the research questions familiar to the author of the present study, suggested another tendency which might disrupt the results of a citation analysis. It is only signaled here, as the author did not conduct satisfactory quantitative research. However, it was apparent that many of the articles studied did not refer to the most important works of a similar, or complementary, thematic scope, published in Polish journals. It is therefore difficult to rely on the results achieved by the method of citation analysis.

Accordingly, the results presented in Table 4 should be approached with an appropriate degree of care. As a result of the limitations discussed above, they might not give an accurate view of real bibliographic couplings between the journals representative of the disciplines studied, and thus, between the disciplines themselves.

Tab. 4. A number of citations of articles published in the studied journals (columns) in the articles in these journals (rows). The journals' full names are abbreviated as they were in Table 3

\begin{tabular}{|c|c|c|c|c|c|c|c|c|c|c|c|c|c|c|c|}
\hline & & 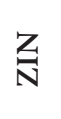 & 乬 & $\stackrel{\bullet}{a}$ & ڤै & 导 & $\frac{\nabla}{s}$ & $\hat{\mathbf{N}}$ & $\sum_{\infty}$ & $\underline{\underline{a}}$ & $\hat{\hat{z}}$ & $\frac{\mathscr{v}}{\underline{z}}$ & $\frac{U}{0}$ & 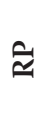 & $\begin{array}{l}\tilde{\Xi} \\
\text { స్ } \\
\text { స్ }\end{array}$ \\
\hline 1 & ZIN & 57 & 10 & 17 & 4 & & & 2 & 1 & & & & & & 91 \\
\hline 2 & PTINT & 30 & 16 & 25 & 2 & 1 & & 1 & & & & & & & 75 \\
\hline 3 & PB & 19 & 4 & 72 & 2 & & & 2 & & & & & & & 99 \\
\hline 4 & TSB & 3 & 1 & 23 & 9 & & & 4 & 1 & & & & & & 41 \\
\hline 5 & AUPC & 5 & 1 & 8 & 3 & 7 & & 4 & & 2 & & & & & 30 \\
\hline 6 & SKI & 1 & & 2 & & & & 1 & & & & & & & 4 \\
\hline 7 & $\mathrm{ZP}$ & & & 2 & & & & 81 & 25 & 3 & 1 & & & 3 & 115 \\
\hline 8 & SM & & & & & & & 8 & 25 & 2 & 2 & 1 & 1 & & 39 \\
\hline 9 & RBP & & & 1 & 1 & & & 29 & 8 & 3 & & & 3 & 1 & 45 \\
\hline 10 & NPD & & & 1 & & & & 17 & 14 & 6 & 2 & 1 & 1 & 2 & 44 \\
\hline 11 & MKKS & & & & & & & 10 & 22 & 2 & 1 & 4 & & 3 & 42 \\
\hline 12 & CEJC & & & & & & & 4 & 4 & & & & 4 & & 12 \\
\hline 13 & $\mathrm{RP}$ & & & & & & & 4 & 2 & & & & & 1 & 7 \\
\hline & Total & 115 & 32 & 151 & 21 & 8 & 0 & 167 & 102 & 18 & 6 & 6 & 9 & 10 & \\
\hline
\end{tabular}


The data presented in Table 4 might suggest that the library and information science has no distinct thematic relation to the media studies, or the cognition and social communication sciences. If they cite other articles at all, the authors of the texts published in the journals affiliated with the discipline of the library and information science cite only the articles published in the journals affiliated with their own discipline. The same is true for the works published in the journals affiliated with media studies, and for those affiliated with the cognition and social communication sciences. Furthermore, the authors of the texts published in $Z I N, P B, Z P$, and $S M$ tend to cite the articles published in the journals in which they publish. The references to articles published in journals associated with other disciplines are only incidental. However, it would be unadvisable to take these results on their face value, as they have been collected with the use of the method which has serious limitations, as discussed above.

The analysis of the frequency with which keywords feature in the articles relied on a set of words and phrases derived from the keywords of these articles which cite other articles published in one of the studied journals at least once. A set of more than eight hundred keywords and key phrases was established for both library and information science, and the media studies with the cognition and social communication sciences. A majority appeared only rarely, in less than ten works. The twenty keywords featured most frequent (between 10 and 100 times) in both groups of journals are featured in Table 5; the eleven most frequent phrases (more than 10 times) - in Table 6.

Tab. 5. The most frequent keywords, from the most to the least frequent (nouns in the singular)

\begin{tabular}{|l|l|}
\hline \multicolumn{1}{|c|}{ The library and information science } & \multicolumn{1}{c|}{$\begin{array}{c}\text { Media studies, and the cognition } \\
\text { and social communication sciences }\end{array}$} \\
\hline $\begin{array}{l}\text { Informacja (Information) } \\
\text { Biblioteka (Library) }\end{array}$ & $\begin{array}{l}\text { Prasa (Press) } \\
\text { Zarządzanie (Management) } \\
\text { Bibliografia (Bibliography) } \\
\text { Wiedza (Knowledge) }\end{array}$ \\
Nauka (Science) & Komunikacja (Communication) \\
System (System) & Radio (Radio) \\
Badania (Research) & Społecznościowe (Social) \\
Książka (Book) & Publiczne (Public) \\
Prasa (Press) & Dziennikarstwo (Journalism) \\
Bibliometria (Bibliometrics) & Kultura (Culture) \\
Cyfrowy (Digital) & Rynek (Market) \\
Czasopisma (Journals) & Analiza (Analysis) \\
\hline Komunikacja (Communication) & Badania (Research) \\
Analiza (Analysis) & Słowa (Words) \\
$\underline{\text { Dane (Data) }}$ & Wolność (Freedom) \\
Dzieci (Children) & Czasopisma (Journals) \\
Hasła (Headings) & Dane (Data) \\
Informatologia (Information science) & Dyskurs (Discourse) \\
Język (Language) & Internet (Internet) \\
\hline
\end{tabular}


Table 6. The most frequent key phrases, from the most to the least frequent

\begin{tabular}{|c|c|}
\hline The library and information science & $\begin{array}{l}\text { Media studies \& cogntivie } \\
\text { and social communications sciences }\end{array}$ \\
\hline $\begin{array}{l}\text { Nauka o informacji (Information science) } \\
\text { Zarządzanie informacją (Information mana- } \\
\text { gement) } \\
\text { Biblioteki akademickie (Academic libraries) } \\
\text { Kompetencje informacyjne (Information } \\
\text { literacy) } \\
\text { Komunikacja naukowa (Scientific communi- } \\
\text { cation) } \\
\text { Język haseł przedmiotowych (Subject he- } \\
\text { adings) } \\
\text { Rozwój dyscyplin naukowych (The develop- } \\
\text { ment of scientific disciplines) } \\
\text { Wyszukiwanie informacji (Information retrie- } \\
\text { val) } \\
\text { Języki informacyjno-wyszukiwawcze (Infor- } \\
\text { mation retrieval languages) } \\
\text { Metody ilościowe w informatologii (Quantita- } \\
\text { tive methods in the information science) } \\
\text { Czasopisma naukowe (Scientific journals) }\end{array}$ & $\begin{array}{l}\text { Media społecznościowe (Social media) } \\
\text { Nowe media (New media) } \\
\text { Wolność słowa (Freedom of speech) } \\
\text { Analiza zawartości (Content analysis) } \\
\text { Fotografia prasowa (Press photography) } \\
\text { Prasa polska (Polish press) } \\
\text { Prasa lokalna (Local press) } \\
\text { Rynek prasy (Press market) } \\
\text { Komunikacja marketingowa (Marketing com- } \\
\text { munication) } \\
\text { Komunikacja elektroniczna (Electronic com- } \\
\text { munication) } \\
\text { Przetwarzanie danych (Data processing) }\end{array}$ \\
\hline
\end{tabular}

The data from both tables indicates that there is only a small overlap between the research fields of these disciplines, noted on the level of single words with a vast scope of reference: press, journal, communication, analysis, data. When we include more precisely identified research fields, described by two or three words long phrases, then we may conclude that each of the two groups of the disciplines has different research interests. However, these sets of key words and phrases might have been affected similarly to the date collected with the method of data citation. The analysis might have been disrupted by the absence of standards for keyword creation, resulting in rather loose descriptions of the articles. Occasionally, the authors will refer to one phenomenon, i.e. excess of information, information overload (information and library sciences), as "the abundance of news" (media studies, cognitive and social communication sciences). However, it should be noted that the indicated limited thematic overlap does correspond to reality. The proximity of data collected with the citation analysis method to those collected with the analysis of specialized terms coexistence confirms as much. Nevertheless, the author remains aware that this convergence may have been achieved with the use of imperfect data samples.

\section{Conclusion}

To answer the question posed in the Introduction, the author has to admit that the joining of the library and information science together with media studies and the cognitive and social communication sciences, as ruled by the Polish Ministry's regulation, is justified by the similarity between their thematic scopes declared in descriptions of these disciplines. 
The analysis of review articles, which consider the thematic scope of the disciplines suggests that, despite frequent application of different concepts and terms, and prioritizing different detail issues in their research, more generally understood, their research fields and objects of studies overlap. Within all three disciplines, Polish researchers were concerned with information objects (sources, resources, tools), among which we should include media and communication tools, as well as communication processes, which encompass mass communication and the influence of media on the society. The researchers studied infrastructure - of information, media, and communication. Every discipline accounted for the individual - a user, a recipient and the author of information, news and media messages. Furthermore, shared research fields and approaches have already emerged in their practice. The study of phenomena and processes which occur online is gaining popularity in all three disciplines. The researchers are increasingly drawn to interdisciplinary topics, inductive approaches, and methods based on quantitative data analysis, frequently collected by at least partially-automatized methods. Therefore, it can be stated that all three disciplines can co-create a new scientific discipline called the social communication and media sciences. However, the practice observed in all three disciplines that researchers mainly publish in journals related to their own discipline and rely solely on the papers published therein, is without a doubt detrimental to the integration of these disciplines.

The research presented in the current study achieved a yet another aim, already suggested in the description of the research process: it has indicated that all investigations of the state of scholarship in any discipline in Poland which rely on quantitative methods, must be conducted with great care, and their results should not be the main basis for drawing conclusions. It has been shown that there are numerous factors disrupting a collection of representative sample of bibliographic data and keywords. The studies based on such data sets may turn out to be misleading and falsifying the picture of the examined reality. The methods applies in the current study are highly dependent on the quality of the used data.

\section{References}

Adamowski, J.W. (2009). O pilnej potrzebie formalnego powołania w Polsce nauki o komunikowaniu i mediach społecznych jako dyscypliny naukowej. Studia Medioznawcze, 4(39), 20-24.

Batorowska, H. (2015). Nauka o informacji (informatologia) z perspektywy nowych wyzwań edukacyjnych. Edukacja-Technika-Informatyka, 3, 73-80.

Dobek-Ostrowska, B. (2006). Komunikowanie polityczne i publiczne. Warszawa: Wydaw. Naukowe PWN.

Goban-Klas, T. (2008). Nauki o mediach i komunikacji społecznej jako nowa dyscyplina nauk humanistycznych. Studia Medioznawcze, 2(33), 11-19.

Goban-Klas, T. (2009). Emergencja nowej dyscypliny: nauki o mediach i komunikacji społecznej. Studia Medioznawcze, 4(39), 14-19.

Górny, M. (2016). Nauka o informacji jako dyscyplina naukowa. W: W. Babik (red.) Nauka o informacji. Warszawa: Wydaw. SBP.

Jabłonowski, M., Gackowski, T. (2012). Tożsamość nauk o mediach. Obszary, perspektywy, postulaty. Studia Medioznawcze, 2(49), 15-24.

Jabłonowski, M., Jakubowski, W. (2014). Status teoretyczny nauk o mediach - kilka uwag do dyskusji. Studia Medioznawcze, 4(59), 11-24.

Jabłonowski, M., Mielczarek, T. (2018). Komunikowanie społeczne i media - federacja, a nie inkorporacja. Studia Medioznawcze, 4(75), 13-27. 
KDN (2018). Nowe rozporzadzenie ws. dyscyplin - to rzetelna ocena badań naukowych [online]. Konstytucja dla nauki [18.09.2018], https://konstytucjadlanauki.gov.pl/nowe-rozporzadzenie-wsdyscyplin-to-rzetelna-ocena-badan-naukowych

Kessler, M.M. (1963). Bibliographic Coupling Between Scientific Papers. American Documentation, 14(1), 10-25.

Kulczycki, E. (2011). Kulturowo-obiektywne istnienie procesu komunikacji jako warunek projektowania autonomicznej dyscypliny komunikacji. Kultura i Historia [online], 21, [18.09.2018], http:// www.kulturaihistoria.umcs.lublin.pl/archives/2997.

Kulczycki, E. (2008). Status komunikologii - przyczynek do dyskusji. Homo Communicativus, 3, 27-37.

Lisowska-Magdziarz, M. (2013). Metodologia badań nad mediami - nurty, kierunki, koncepcje, nowe wyzwania. Studia Medioznawcze, 2(53), 27-42.

Sosińska-Kalata, B. (2013). Obszary badań współczesnej informatologii (nauki o informacji). Zagadnienia Informacji Naukowej - Studia Informacyjne, 2(102), 9-41.

\title{
Analiza związków tematycznych bibliologii $\mathrm{i}$ informatologii z pozostałymi subdyscyplinami nauk o komunikacji społecznej i mediach w Polsce
}

\begin{abstract}
Abstrakt
Cel/Teza: Połączenie w ramach jednej dyscypliny naukowej - nauk o komunikacji społecznej i mediach - trzech dotychczas odrębnych dyscyplin: bibliologia i informatologia (nauki humanistyczne), nauka o mediach oraz nauki o poznaniu i komunikacji społecznej (nauki społeczne) skłoniło autora do szukania odpowiedzi na pytania: czy połączenie tych dyscyplin, bazujące na systematyce OECD, jest uzasadnione podobieństwem problematyki badawczej? Czy w dotychczasowej praktyce naukowej pojawiły się wspólne obszary i podejścia badawcze?

Koncepcja/Metody badań: Zakres tematyczny poszczególnych nauk ustalono poprzez analizę treści artykułów przeglądowych poświęconych problematyce badawczej poszczególnych dyscyplin naukowych oraz informacji o zakresie tematycznym czasopism związanych ze wspomnianymi dyscyplinami, podawanych na ich stronach WWW. Ustalone w ten sposób informacje skonfrontowano z danymi bibliograficznymi i zestawami słów kluczowych, pochodzącymi z czasopism związanych z badanymi naukami, za pomocą metody analizy cytowań oraz metody współwystępowania specjalistycznej terminologii naukowej.

Wyniki i wnioski: Analiza artykułów przeglądowych pozwoliła na postawienie tezy mówiącej, że podstawowe obszary badawcze bibliologii i informatologii z jednej strony, a nauki o mediach oraz nauk o poznaniu i komunikacji społecznej z drugiej, są ze sobą zbieżne i nawzajem się uzupełniają. Powyższą konstatację potwierdza też analiza informacji dla potencjalnych autorów artykułów, zamieszczona na stronach WWW badanych czasopism. Jednak analiza danych bibliograficznych i zestawów słów kluczowych nie potwierdziła tego wniosku, dała zupełnie odmienny obraz - braku istotnych związków tematycznych pomiędzy badanymi dyscyplinami. Jednakże taki wniosek może być skutkiem ograniczeń zbiorów danych zastosowanych w obu metodach i podatności tychże metod na zaburzenia danych.

Oryginalność/Wartość poznawcza: Główna wartość poznawcza pracy sprowadza się do identyfikacji zakresu związków bibliologii i informatologii z naukami o komunikacji społecznej i mediach. Ponadto wykazano istnienie ograniczeń do stosowania metody analizy cytowań oraz metody współwystępowania specjalistycznej terminologii naukowej, stwarzanych przez samych autorów i redakcje części
\end{abstract}


czasopism. Udowodniono, że wszelkie analizy stanu dyscyplin naukowych, w których stosuje się metody ilościowe, w polskich realiach muszą być prowadzone z dużą ostrożnością, a ich wyniki nie powinny stanowić głównej podstawy do wyciągania wniosków.

\section{Słowa kluczowe}

Analiza cytowań. Analiza współwystępowania terminów specjalistycznych. Bibliologia i informatologia. Bibliotekoznawstwo i nauka o informacji. Medioznawstwo. Metoda powiązań bibliograficznych. Nauki o komunikacji społecznej i mediach. Nauki o poznaniu i komunikacji społecznej.

Dr habil. ZBIGNIEW OSIŃSKI is Professor at the Department of Digital Humanities at the Maria Curie-Sktodowska University Lublin. He specializes in information science and digital humanities. His most important publications include: M. Górny, M. Kisilowska, E. Gtowacka, Z. Osiński: Mechanisms of the formation and evolution of personal information spaces in the humanities (Poznań, 2017); M. Kowalska, V. Osińska, Z. Osiński: The Role of Visualization in the Shaping and Exploration of the Individual Information Space (Knowledge Organization, 2018); Z. Osiński: Information infrastructure of contemporary humanities and the digital humanities development as a cause of creating new information barriers. A Polish case (Digital Scholarship in the Humanities, 2019).

Contact to the Author:

zbigniew.osinski@gmail.com

Department of Digital Humanities

Faculty of Humanities

Uniwersytet Marii Curie-Skłodowskiej

pl. Marii Curie-Sktodowskiej 4

20-031 Lublin, Poland 